\title{
A imbricada relação do setor financeiro com a reprodução do espaço urbano: entre a renda fundiária e a renda do capital como alavancas do fluxo de valor
}

Les connexions intimes entre le secteur financier et la reproduction de l'espace urbain: entre revenus fonciers et revenus du capital comme leviers de flux de valeur

The imbricated relationship of the financial sector with the reproduction of urban space: between land income and capital income as value flow levers La relación imbricada del sector financiero con la reproducción del espacio urbano: entre la renta de la tierra y la renta del capital como palancas de flujo de valor

\section{Frederico Basso Montanari}

\section{OpenEdition}

Journals

\section{Edição electrónica}

URL: https://journals.openedition.org/espacoeconomia/20242

DOI: 10.4000/espacoeconomia.20242

ISSN: 2317-7837

Editora

Núcleo de Pesquisa Espaço \& Economia

Refêrencia eletrónica

Frederico Basso Montanari, «A imbricada relação do setor financeiro com a reprodução do espaço urbano: entre a renda fundiária e a renda do capital como alavancas do fluxo de valor», Espaço e Economia [Online], 22 | 2021, posto online no dia 14 janeiro 2022, consultado o 11 agosto 2022. URL: http://journals.openedition.org/espacoeconomia/20242 ; DOI: https://doi.org/10.4000/ espacoeconomia.20242

Este documento foi criado de forma automática no dia 11 agosto 2022.

Creative Commons - Atribuição-NãoComercial-Compartilhalgual 4.0 Internacional - CC BY-NC-SA 4.0 https://creativecommons.org/licenses/by-nc-sa/4.0/ 


\section{A imbricada relação do setor financeiro com a reprodução do espaço urbano: entre a renda fundiária e a renda do capital como alavancas do fluxo de valor}

Les connexions intimes entre le secteur financier et la reproduction de l'espace urbain: entre revenus fonciers et revenus du capital comme leviers de flux de valeur

The imbricated relationship of the financial sector with the reproduction of urban space: between land income and capital income as value flow levers La relación imbricada del sector financiero con la reproducción del espacio urbano: entre la renta de la tierra y la renta del capital como palancas de flujo de valor

\section{Frederico Basso Montanari}

\section{Introdução}

1 Em que consiste o regime de acumulação financeirizado? Podemos falar em financeirização do espaço urbano como uma nova estratégia de reprodução do capital? Qual a relação entre a ascensão do regime de acumulação financeirizado e a produção alienadora do espaço urbano?

2 À luz dessas questões postas logo de início que desenvolveremos o presente trabalho. Partiremos das origens do domínio financeiro no modo de produção capitalista para, posteriormente, dedicarmos atenção à financeirização do urbano e à produção alienadora do espaço. Ao fim, buscaremos oferecer um quadro amplo sobre as 
transformações das relações sociais de produção e das novas estratégias de reprodução do capital.

3 Desta feita, temos que o objetivo deste trabalho é analisar a imbricada relação do setor financeiro com o processo de empresariamento urbano nas novas formas de gestão urbana que emergiram nos últimos 40 anos, buscando conexões entre o financeiro e a reprodução do espaço. A partir dessa análise procuraremos contribuir para a discussão do caráter dialético da relação entre a produção do espaço urbano e a financeirização.

4 Faz-se necessário, portanto, uma breve reconstrução da "nova" trajetória do modo capitalista de produção - do final do século XX e início do século XXI - visto que é nesse contexto que a reprodução do espaço ganhará centralidade no processo de acumulação (CARLOS, 2017), sob o signo daquilo que Chesnais (2002) denominou de regime de acumulação financeirizado. Na medida em que resgatarmos essa trajetória recente do modo de produção capitalista - que estará na primeira seção após a introdução, estabeleceremos os laços entre a financeirização e a produção do espaço urbano segunda seção do artigo, identificando limites e contradições presentes nessa metamorfose, bem como esclarecendo “... os problemas e processos marcados pela emergência do financeiro e do imobiliário na produção do espaço contemporâneo" (PEREIRA, 2015, p. 172), uma produção cada vez mais alienadora do espaço - terceira seção do artigo. Por fim, teceremos algumas ponderações acerca do exposto nas considerações finais.

\section{A ascensão do regime de acumulação financeirizado: entre vigaristas e profetas ${ }^{1}$}

5 Procurar as "origens" do domínio financeiro no modo de produção capitalista é essencial para que possamos compreender melhor as condições atuais da produção do espaço urbano. Por isso, dedicaremos esta seção à contextualização histórico-geográfica em que o setor financeiro passou ao plano central da acumulação capitalista.

6 Cabe, de início, apresentarmos uma definição sobre o processo de financeirização da economia ou o regime de acumulação financeirizado. Baseando-nos em diferentes autores, como Aalbers (2015), Chesnais (1998; 2002), Arrighi ([1996] 2006), Harvey ([1982] 2013), entendemos a financeirização como um processo amplo, com abrangência tanto social quanto econômica e política, mobilizando diferentes escalas geográficas e no qual encontramos diferentes atores que sustentam suas ações numa sólida base institucional e cultural. Segundo Aalbers (2015, p. 214. Apud. KLINK, J. e BARCELLOS, M. 2017, P. 381):

A crescente dominância de agentes, mercados, práticas, métricas e narrativas financeiros, nas múltiplas escalas, o que tem gerado uma transformação estrutural das economias, das corporações (incluindo instituições financeiras), dos Estados e das famílias.

Essa crescente dominância do financeiro indicada por Manuel Aalbers vem ocorrendo, como sabemos, desde as crises dos anos de 1970, conduzindo a uma mudança "na configuração espacial dos processos de acumulação de capital" (ARRIGHI, [1996] 2006, p. 1), e o espaço urbano está no bojo de tais reconfigurações. Lembremos que nos anos dourados do século XX (décadas de 1950 e 1960), o fenômeno urbano esteve associado à industrialização e à aglomeração, lógicas espaciais inerentes ao modelo fordista de produção. Tal período corresponde ao embrião do processo de metropolização e, 
portanto, a urbanização é muito mais uma consequência da industrialização fordista. As economias nacionais dos países centrais eram sustentadas pelo formidável crescimento das economias domésticas. Os Estados Unidos da América, por exemplo, quase não extraíam valor do resto do mundo (HARVEY, [2003] 2014) e a acumulação de capital das principais economias mundiais seguia a mesma receita, "reprodução expandida" onde "os lucros eram reinvestidos tanto no crescimento como em novas tecnologias, capital fixo e amplas melhorias infraestruturais (HARVEY, [2003] 2014, p. 54).

8 A explosão no setor produtivo, característica dessa fase, inundava o mercado mundial com dólares excedentes e o sistema de Bretton Woods era sistematicamente corroído. A alternativa foi, então, abandonar o padrão dólar-ouro e inaugurar um novo sistema monetário internacional: flutuante e desmaterializado. Para Harvey ([2003] 2014 p. 58), "ameaçados no campo da produção, os Estados Unidos reagiram afirmando sua hegemonia por meio das finanças". Cabe salientar que esse "novo viés" do imperialismo estadunidense passou a ser sustentado por atores como o FMI (Fundo Monetário Internacional), o Banco Mundial e o Departamento do Tesouro dos EUA, que abriram o caminho para a virada ao regime de acumulação financeirizado e a expansão da "acumulação por espoliação".

9 Portanto, podemos afirmar que a transição dos anos 1960 e início dos anos 1970 sinalizou para o esgotamento do binômio keynesiano-fordista, sob o qual a cidade - e o urbano - serviam, principalmente, como base ao modo de produção, ou seja, suporte às atividades do secundário e tudo que estivesse a ele envolvido. Lembremos que as duas grandes crises do petróleo (1973 e 1979) desestabilizaram ainda mais as bases do sistema fordista ao passo que o acordo de Bretton Woods (1944) desmoronava, como dissemos anteriormente. $O$ delicado equilíbrio entre os poderes financeiros e estatais rompia-se, dando sinais de um aumento do poder do capital financeiro frente ao Estado Nacional.

10 A guinada em favor ao capital financeiro ficou marcada pela ascensão das políticas neoliberais, pelo desmonte do estado de bem-estar, pelo domínio do modelo de acumulação flexível e, portanto, pela nova fase do capitalismo. 0 curto período entre 1968 e 1973 produziu o embrião da expansão financeira dos anos de 1970 e 1980, principalmente através do forte aumento no mercado de eurodólares (dólar depositado em bancos estrangeiros, destaque para Londres e o mercado europeu). Tal fato levou o governo estadunidense a abandonar o padrão de câmbio ouro-dólar em 1971 e, já em 1973, o Federal Reserve e os demais bancos centrais "tiveram de reconhecer sua derrota na luta para deter a maré de especulação crescente contra o regime de taxas de câmbio fixas" (ARRIGHI, [1996] 2006, p. 310), permitindo ao mercado o controle dos preços das moedas nacionais umas em relação às outras e ao ouro (ARRIGHI, [1996] 2006, p. 310). Revogava-se o acordo de Bretton Woods.

11 O fim do padrão-ouro para o dólar abriu caminho para o sistema de câmbios flexíveis e uma instabilidade monetária crônica. Por esse motivo, afirma-se que o mercado de câmbio foi o "primeiro compartimento a entrar na mundialização financeira" (CHESNAIS, 1998, p. 25). Além da revogação de Bretton Woods, devemos lembrar que as contradições abafadas no período keynesiano-fordista começavam a estrangular a reprodução do capital, já que havia uma crescente dificuldade em se buscar a valorização por meio da produção, levando à formação de uma enorme "massa de capitais procurando valorizar-se de forma financeira" (CHESNAIS, 1998, p. 17). 
12 Para que essa massa de capitais pudesse se valorizar na esfera financeira, mudanças radicais na política econômica dos Estados deveriam acontecer, como a liberalização dos fluxos financeiros, desregulamentação dos mercados nacionais, políticas monetárias favoráveis e flutuantes, integração instantânea entre as principais praças financeiras do mundo etc. Esse cenário favoreceu a emergência de um novo binômio, neoliberal e pós-fordista e figuras como Ronald Reagan (1980-1988) e Margareth Thatcher (1979-1990) passaram a representar muito bem o "novo" nexo entre Estado e finanças ao desmontarem o Welfare State e implantarem as políticas neoliberais em seus países, as quais tinham por objetivo preservar uma estrutura institucional (como os sólidos direitos à propriedade privada) favorável ao livre comércio e a liberdade de mercado. Ribeiro e Diniz (2017), ao citarem Zygmunt Bauman, reforçam a ideia de que a financeirização corresponde, também, à transição de uma "sociedade de produtores, na qual os lucros provinham da exploração do trabalho, para uma sociedade de consumidores, na qual os lucros se fundamentam na exploração dos desejos de consumo" (RIBEIRO e DINIZ, 2017, p. 370).

Como vimos, Arrighi ([1996] 2006) afirma que essa nova conjuntura tem proporcionado mudanças dramáticas na configuração espacial dos processos de acumulação de capital, onde a tendência predominante sinalizava para uma simples realocação dos processos de acumulação em direção aos países subdesenvolvidos, consolidando a desconcentração espacial da produção industrial (deseconomia de aglomeração). Contudo, tal desconcentração não significou a descentralização do capital, pelo contrário, estava em curso um processo de centralização do capital em países nucleares (capitalistas avançados), em destaque os Estados Unidos e Reino Unido. A classe financista de Wall Street e da City de Londres ganhava força. Para Aglietta (1986, p.195):

Enquanto a concentração simples é, dentro do campo do valor, um feito quantitativo de acumulação desigual que conserva a autonomia dos capitais, a centralização é uma modificação qualitativa que remodela a autonomia dos capitais e cria novas relações de competição (disputa).

Nesse sentido, podemos falar que os investimentos na expansão do comércio e da produção não mais atendiam aos interesses da classe financista e as negociações puramente financeiras demonstravam maior "eficiência". Dessa maneira, cada vez menos capital excedente passou a ser absorvido na produção, direcionando-se para a especulação de ativos. Podemos dizer, em conformidade com Harvey (2011, p. 33), que "a virada para a financeirização desde 1973 surgiu como uma necessidade. Ofereceu uma forma de lidar com o problema da absorção do excedente".

\section{Financeirização e urbanização: novas estratégias de reprodução do capital}

15 Após a análise das singularidades presentes no regime de acumulação com domínio financeiro, vamos agora buscar conexões entre tal regime e as recentes transformações espaciais. Esse diálogo entre financeirização e urbanização é essencial para que possamos “...realizar a necessária distinção crítica entre os rendimentos da propriedade do dinheiro e da propriedade da terra, como capital e como bem patrimonial" (PEREIRA, 2017, p. 208). Além disso, o binômio privatização e liberalização, quintessência do receituário neoliberal, vem imprimindo pelo mundo uma série de expropriações das terras comuns. Desde os ativos estatais aos comuns urbanos, de uso partilhado, vêm sendo "entregues ao mercado para que o capital sobreacumulado" 
possa "investir neles, valorizá-los e especular com eles (HARVEY, [2003] 2014, p. 130-131). Apossar-se desses ativos e comuns urbanos implica num bárbaro processo de despossessão, já indicados por Harvey ([2003] 2014) e por Arundhati Roy (Power Politics, 2001). Portanto, há de se reforçar o caráter dialético da relação entre a produção do espaço urbano e a financeirização, bem como a dialética entre preço e valor, a fim de contribuirmos para as discussões que envolvem "a produção do espaço, a urbanização planetária, a financeirização e a globalização que podem (ou precisam) ser reunidas e discutidas no âmbito da teoria do valor para sua melhor compreensão" (PEREIRA, 2017, p. 172). Paulo Cesar Xavier Pereira vai além, ressaltando que as discussões sobre a relação dialética entre preço e valor podem auxiliar, também, a "esclarecer os problemas e processos marcados pela emergência do financeiro e do imobiliário na produção do espaço contemporâneo (PEREIRA, 2017, p. 172).

Portanto, o objetivo neste tópico é de verificar que cada regime de acumulação se materializa no espaço, tomando forma através de normas, hábitos, leis, redes de regulamentação etc., as quais garantem o esquema de reprodução (HARVEY, 2008, p. 117) e, dessa maneira, buscaremos compreender as formas que o setor financeiro vem desenvolvendo para garantir seus ganhos através do ambiente construído. Vale destacar que tais transformações implicam numa máxima mercantilização das cidades, as quais entraram nos circuitos da valorização financeirizada ampliando "a tendência geral de transformação do espaço urbano e um campo aberto para a circulação de capitais portadores de juros, o que permite uma aliança entre proprietários de terra e capitalistas e só é possível à medida que são deslocadas as demais formas de propriedade" (RIBEIRO e DINIZ, 2017, p. 367).

Comecemos por Karl Marx, o qual já apontava no Livro III que o capital portador de juros é a "matriz de todas as formas insanas de capital" (MARX, 2017, p. 523). A insanidade advém de o fato do capital-dinheiro retornar à função de mercadoria, na qual seu valor de uso é dado a partir da capacidade de criar mais-valor e seu valor de troca são os juros. Para Harvey (2018, p. 173), "o próprio dinheiro, que é a representação do valor, adquire um valor monetário". O regime de acumulação financeirizado é, portanto, o momento de domínio do antivalor, onde "se completam a forma fetichista do capital e a ideia do fetichismo do capital" (MARX, 2017, p. 442) pois o capital portador de juros se torna a principal alavanca do fluxo do valor: a magia do dinheiro que é capaz de criar mais dinheiro!

Klink e Barcellos (2017, p. 382) lembram que "a financeirização está umbilicalmente ligada as relações sociais e ao conflito entre capital e trabalho" e, dessa maneira, ligada à reprodução do espaço urbano e às novas lutas pelo direito à cidade. Nas palavras de Luiz César de Queiroz Ribeiro e Nelson Diniz (2017, p. 352):

Como se sabe, as mudanças urbanas e territoriais típicas da atual fase de desenvolvimento do capitalismo expressam, cada vez mais, uma lógica geral de produção social do espaço que está determinada pelas novas formas de acumulação financeirizada.

19 Assim, quando falamos em financeirização do urbano deparamo-nos com uma das loucuras da razão econômica, que é a ficção criada tanto na renda fundiária quanto na crença de que o dinheiro tem um preço. A ficção da renda fundiária advém do fato de tratarmos a terra como uma mercadoria que tem preço, mas não tem valor. Já o sistema de crédito se sustenta na ficção de que o dinheiro é uma mercadoria que possui um preço e, portanto, o que era representação do valor passa a possuir um valor efetivo. 
Como assertivamente nos lembra Harvey (2018), bancos e instituições financeiras buscam a maximização do lucro, mesmo que não ocorra produção efetiva decorrente dos empréstimos. Eles - bancos e instituições financeiras - colocam o capital portador de juros em circulação, reivindicando sua parte do mais-valor sem contribuir para a produção efetiva, ou seja, apenas lastreados nos direitos de propriedade dados pela posse do dinheiro. Isso significa que os empréstimos podem buscar lucro através da especulação imobiliária (compra de terrenos, compra de imóveis construídos etc.), o que - nas palavras de Marx (2017, p. 442) - corresponderia ao momento no qual "se completam a forma fetichista do capital e a ideia do fetichismo do capital". Ou seja, "toda a produção capitalista é especulativa, é claro, mas no sistema financeiro essa característica é exacerbada, transformando-se em fetiche supremo" (HARVEY, 2018, p. 49).

Insistimos sobre o fetiche supremo inerente ao sistema financeiro pois, na "fantasia" que envolve o regime de acumulação financeirizado e o domínio do antivalor do capital fictício, a demanda efetiva tem sido cada vez mais sustentada pelo sistema de crédito (empréstimos) e pelas reivindicações sobre a produção futura de valor, que crescem exponencialmente:

O crédito escoa para proprietários fundiários e imobiliários. Alimenta a especulação com aluguéis e outros valores de ativos que, em seguida, ganham o poder de aumentar magicamente e sem limite. Comerciantes e industriais contraem empréstimos mesmo diante do robusto poder do antivalor, que pode vir a destruílos no futuro (HARVEY, 2018, p. 176).

21 Portanto, ao considerarmos as novas formas de acumulação financeirizada temos que o solo urbano passa, ubiquamente, a representar capital fictício e mercadoria fictícia, "não apenas um negócio, mas um negócio líquido e rentável" (RIBEIRO e DINIZ, 2017, p. 368) onde a reprodução do capital "combina a valorização pela exploração do trabalho e a capitalização da renda por processos que espoliam a sociedade" (PEREIRA, 2017, p. 190). Ainda sobre a financeirização do urbano, lembremos que ela é inconsequentemente sustentada por irracionalidades, sobretudo aquelas que têm como base a incongruência qualitativa entre valor e preço. Um bom exemplo explorado por Harvey $(2018$, p. 99) se refere a situações nas quais o capitalista prefere aplicar seus investimentos no mercado imobiliário ou em outras formas especulativas, deixando de participar "do processo de reprodução do capital enquanto totalidade em evolução". Vale lembrar, como destacou Rufino (2017, p. 217) ao citar Topalov (1974), que a produção imobiliária apresenta "o longo período de produção, o longo período de circulação e a necessidade da terra".

Em um dos livros mais recentes, Harvey (2016) trabalha com aquilo que ele considera as "17 contradições do capital". Entre as contradições ele destaca a presença de um lucro excedente que pode ser convertido em renda, como acontece em situações de financeirização do urbano em que o capital excedente disponível no setor financeiro é drenado para o ambiente construído. Exacerbam-se as contradições entre a renda proveniente do dinheiro - juros do mercado financeiro - e a renda proveniente da terra - fundiária, as quais passam a ter a mesma origem. Harvey (2013, p. 457) lembra que neste caso o "proprietário da terra então recebe tanto a renda quanto os juros, enquanto o produtor fica confinado ao lucro do empreendimento, que, em condições particularmente repressivas, pode terminar próximo ao salário de subsistência". 0 movimento do capital financeiro, de credor para proprietário, traz a expectativa de 
direito a uma renda cada vez maior. Como salientou Chesnais ([1995] 1998), essa mudança estrutural é a alma da financeirização.

Diante do exposto acima, torna-se premente - neste momento - dedicarmo-nos à discussão acerca do princípio do valor e a teoria da renda, com o intuito de abrirmos caminho em direção às relações entre setor financeiro e a reprodução do espaço urbano. Tal discussão será balizada, quase que integralmente, por um trabalho realizado pelo Professor Paulo César Xavier Pereira para o III SIMEGER (Simpósio Internacional sobre Metropolização do Espaço, Gestão Territorial e Relações UrbanoRurais). Pereira (2017, p. 182) questiona se a "emergência mundial das finanças sobre o capital produtivo" poderia alterar o princípio do valor e, para tanto, a expansão financeira teria como interesse escavar as rendas fundiárias do solo urbano, libertandose das amarras do valor para então se transmutar numa financeirização urbanizadora, componente essencial da atual metropolização do espaço. Insistindo na relação setor financeiro e urbanização, Pereira (2017, p. 186) estabelece uma profunda associação entre Lefebvre e Chesnais; para ele:

[...] o espaço como condição, meio e resultado dessa produção tem na terra um elemento indissociável, um valor de uso que privatizado e comercializado tem preço. Por isso, expressa valor de mercado, mas por não ser um resultado do trabalho, não contém tal substância, o seu "valor" é apenas uma expressão do preço.

Temos que a condição de financeirização do urbano caminha para uma situação limite em que o valor referente ao solo urbano perde seu referencial - o trabalho, ao passo que temos a imobilização de capital excedente - e sobreacumulado - no território. Esse cenário se dá, pois, a demanda por excedente de valor vem se sustentando através do binômio financeirização e produção do espaço (PEREIRA, 2017), o qual "vem realizar com destaque a função de criar uma sobrevida para a reprodução de relações capitalistas" (PEREIRA, 2017, p. 183) e, ainda conforme o autor, "assegurando a sobrevivência do capitalismo".

Resgatando as fundamentais teorias desenvolvidas por Karl Marx, Pereira (2017) reforça que para melhor compreendermos a produção contemporânea do espaço devemos problematizar a distinção entre capital e renda, a partir da relação entre preço e valor presente em tal produção. Portanto:

O espaço mobilizado como riqueza imobiliária e financeira passa continuamente a valer mais (os preços no mercado de terra e no dinheiro se realimentam incessantemente). Essa combinação cria liquidez e manipula a raridade do espaço, favorecendo a produção do espaço e do valor a tal ponto que ela alcança o nível da economia mundial. A propriedade da terra e propriedade do dinheiro se ativam mutuamente na mobilização do espaço pelo capital (PEREIRA, 2017, p. 187).

Como já indicamos acima, para Pereira (2017, p 192) o espaço produzido - resultado do trabalho humano - é uma mercadoria que contém valor "a partir do qual uma parte da mais-valia que ela realiza expressa o preço da terra sob forma de renda capitalizada", ou seja, uma "transfiguração da mais-valia do produto imobiliário". Porém, o domínio do setor financeiro sobre a captura desse valor sustenta-se num paradoxo pois "contém, nela própria, uma parte da mercadoria produzida (o edifício, como coisa construída) e, outra, que não é resultado de trabalho (a terra) " (PEREIRA, 2017, p. 192).

É, portanto, a partir da produção imobiliária financeirizada que se escancara a contradição qualitativa preço e valor. Isso acontece "porque o preço do produto imobiliário no mercado não é regulado pelo preço de produção" (PEREIRA, 2017, p. 197). 
Lembremos que ao longo das fases de expansão produtiva - como no período de domínio do regime de acumulação keynesiano-fordista - o preço de produção (geral) sobrepõe-se à renda capitalizada da terra, sustentando o mercado imobiliário através dos preços de monopólio. Porém, "atualmente, essa contradição exacerba-se pelo fato de que ficaram ainda mais potencializados os ganhos rentistas (mobiliários e imobiliários), cuja capitalização é feita na ótica do capital financeiro" (PEREIRA, 2017, p. 197). Assim, ainda à luz do proposto por Marx:

O valor designado sob a forma de dinheiro (preço) constitui-se na representação monetária do trabalho incorporado na produção da mercadoria. Sendo assim [a Construção especialmente], "não só admite a possibilidade de divergência quantitativa entre magnitude de valor e preço, isto é, entre magnitude do valor e sua própria expressão de dinheiro, mas também pode esconder uma contradição qualitativa, de modo que o preço deixa de ser a expressão do valor, embora dinheiro seja apenas a forma do valor das mercadorias" (MARX, livro I, p.115. Apud. PEREIRA, 1988, p.10, grifo nosso) (PEREIRA, 2017. P.197).

Isso significa que o mercado imobiliário compõe uma parte inseparável da produção do espaço e, portanto, o ambiente construído tem um valor de uso, um valor de troca e um valor (HARVEY, [1982] 2013, p. 316). Quanto ao valor de troca referente ao mercado imobiliário, temos "o valor de mercado derivado do 'aluguel capitalizado' e o que resulta do "preço de produção"' (PEREIRA, 2017, p. 197). Haverá uma discrepância entre tais valores de troca, levando a uma "incoerência na lei do valor porque 'os dois preços são derivados de maneira totalmente diferentes, mas são conciliados em uma única estrutura de preço pelo sistema de mercado"' (HARVEY, [1982] 2013, p.316 e 317. Apud. PEREIRA, 2017, p. 197).

Os indícios da contradição que envolve a financeirização urbanizadora são muitos. Para Marx o monopólio proveniente da propriedade fundiária - sobre determinadas áreas do globo - atua como um obstáculo para os investimentos na terra, ou seja, a "propriedade privada da terra ergue barreiras ao processo de equiparação na distribuição intersetorial da mais-valia gerada pelo capital global" (PAULANI, 2016, p. 521), ou seja:

[...] a questão chave é que o imóvel representa um valor de troca sempre maior e independente da produção. Essa "normalidade" seria em função de que o preço de monopólio se forma com autonomia em relação ao valor, podendo chegar "às nuvens" no que depender do desejo e da capacidade dos compradores (PEREIRA, 2017, p. 198).

O espanto de Paulani (2016, p. 527) com o "rentismo envolvido na exploração econômica dos recursos contidos no subsolo", que nas palavras da autora "se trata de transformar em valor excedente recursos esgotáveis", deve ser estendido à produção do espaço urbano com base no regime de acumulação financeirizado, o qual também transforma em valor excedente recursos esgotáveis como o solo urbano!

Há como superar essa contradição imanente? Para Paulani (2016, p. 528), inspirada em David Harvey ([1982] 2013), uma das maneiras é deslocando-se a contradição através do espaço geográfico (sem resolvê-la), condição que exacerba "a importância da localização como geradora de renda, bem como sua complexa e profícua relação com o capital financeiro". Para Harvey ([1982] 2013) a contradição entre a lei do valor e a renda fundiária só pode desaparecer quando o espaço se torna um campo aberto à circulação do capital portador de juros, tornando-se assim um capital fictício. Como salientou Paulani (2016, p. 528) "o preço da terra deve refletir a permanente busca do capital por rendas futuras aumentadas [...] de modo a garantir sempre os melhores e mais lucrativos usos e a maximizar a produção de valor excedente". Portanto, a 
financeirização urbanizadora leva à "utilização da terra como capital portador de juros" o que "permite uma aliança ativa entre proprietários de terra e capitalistas" (PAULANI, 2016, p. 528). Assim:

[...] a transformação da terra num campo aberto à circulação do capital portador de juros significa não só a dominação do poder social da terra pelo poder social do dinheiro, como a subsunção da primeira ao processo de acumulação, ao atribuir aos proprietários de terra o papel ativo de dar fluidez e dinamismo ao mercado de terras.

Vale lembrar que os avanços nos meios de telecomunicações e de transportes tiveram e ainda têm - forte papel no redimensionamento e na reestruturação da economia mundial e nos fluxos de capital excedente. A ascensão financeira ganhou tamanha proporção pois os fluxos, sobretudo de capitais, intensificaram-se numa ordem jamais esperada. Agora o capital fictício consegue facilmente transitar entre os diferentes setores da economia através dos investimentos de portfólio ("hot money" ou "foot loose $\mathrm{e}^{2}$ "), buscando sempre a maior rentabilidade e, em alguns casos, a maior rentabilidade está na produção do espaço. Portanto, o excedente de capital produzido na Ásia e acumulado em fundos de investimentos norte-americanos podem ser direcionados na produção do espaço urbano de uma cidade brasileira, ou seja, tal processo representaria a inversão de capital na produção do espaço urbano, associando a renda baseada no capital (juros) e aquela baseada na terra (fundiária).

Essa contradição se amplia (demanda por agilidade no fluxo de capital X inversão no espaço urbano), pois a produção do espaço é uma condição de reprodução capitalista e o espaço construído deve sempre responder as exigências do modo de produção capitalista. Nesse sentido, podemos afirmar há uma profunda conexão entre a forma de funcionamento do regime financeirizado e a produção do espaço urbano metropolizado. Segundo Harvey (2013, p. 503):

As necessidades peculiares da circulação do capital nos ambientes construídos têm significado a evolução de um tipo especial se sistema de produção e realização que define novos papéis para os agentes econômicos. Os proprietários de terra recebem renda, os empresários recebem aumentos na renda baseados nas melhorias, os construtores ganham o lucro dos juros, os financistas proporcionam capital monetário em troca dos juros, ao mesmo tempo que podem capitalizar qualquer forma de receita acumulada pelo uso do ambiente construído em um capital fictício (preço da propriedade) e o Estado pode usar os impostos (atuais ou antecipados) como suporte para investimentos que o capital não pode ou não vai realizar, mas que não obstante expande a base para a circulação local do capital. Esses papéis existem não importa quem o desempenha.

Ainda sobre a conexão entre a financeirização da economia capitalista e a produção do espaço urbano, Sanfelici (2013, p. 01) aponta que o setor imobiliário brasileiro se reestruturou como nunca antes por conta do enorme montante de capital drenado na expansão desse setor. Para ele, isso têm significado "uma penetração sem precedentes das finanças na produção e no consumo do espaço urbano intermediada pelas empresas do setor imobiliário", ou seja, "as grandes incorporadoras (...) passaram a financiar o investimento mediante o recurso ao mercado de capitais".

Um dos mecanismos criados para permitir a entrada de capital financeiro no setor imobiliário brasileiro foi a difusão dos IPO's (Initial Public Offering ${ }^{3}$, que corresponde a abertura de capital na bolsa de valores). Um dos critérios para aferir valor das empresas de capital aberto passou a ser o estoque de terras (land banks ${ }^{4}$ ) bem como a quantidade de lançamentos realizados pelas incorporadoras. Tal mecanismo funciona como um elo 
entre as demandas do capital financeiro globalizado (escala global) com a produção e reprodução do espaço urbano das grandes metrópoles brasileiras (escala local).

Outra face da financeirização do espaço urbano se relaciona ao sistema de crédito imobiliário, o qual oferece condições para o acesso ao imóvel para o trabalhador urbano. Até os anos 1990 a oferta de crédito imobiliário no Brasil era bastante restrita $\mathrm{e}$ de pouca amplitude; a política habitacional brasileira era centralizada no Banco Nacional de Habitação (BNH), o qual canalizava recursos para produção do ambiente construído. Porém, em 1986 o BNH foi dissolvido mediante a profunda recessão da década de 1980 e, assim, enfraqueceu-se a única política habitacional brasileira. Somente em 1997 que a oferta de créditos imobiliários voltou a ganhar fôlego no mercado brasileiro através da criação do SFI (Sistema de Financiamento Imobiliário). Além desse fator, podemos destacar o forte crescimento da economia brasileira na primeira década dos anos 2000 o que facilitou o acesso ao crédito e, assim, o acesso ao imóvel.

Portanto, como já mencionamos acima, há uma evidente relação entre a financeirização e a produção do espaço urbano brasileiro a partir da primeira década do século XXI. Seja pela forte entrada de investimentos internacionais nas incorporadoras brasileiras de capital aberto, seja pela maior oferta de crédito imobiliário cedido ao mercado brasileiro. Ambas as dimensões buscam escavar ao máximo as rendas provenientes do solo urbano, seja pelo retorno aos antigos centros e às regiões portuárias ou pela expansão da área construída nos bairros afastados. Esse duplo movimento - antigos centros e orla urbana - coincide com a maior pujança das incorporadoras, maior penetração do capital financeiro internacional e à explosão dos preços do solo urbano das principais metrópoles brasileiras. Fica exposto o imperativo dos resultados de curto prazo quando associamos o planejamento pautado pelo empresariamento urbano ao regime de financeirização (KLINK e BARCELLOS, 2017). Entrelaçando os diferentes níveis hierárquicos podemos perceber que a financeirização também ocorre através da penetração do crédito na vida cotidiana (hipotecas, crédito imobiliário etc.), conduzindo à formação daquilo que Aalbers (2012) chamou de Subprime Cities. Aglietta (1998) e Chesnais (2002) afirmam que o regime de financeirização consolida um "capitalismo de amanhã", sustentado através das rendas futuras. Se, contudo, considerarmos o estreitamento do setor financeiro com a produção do espaço urbano financeirização urbanizadora - teremos a formação de "cidades do amanhã".

Por fim, um dos principais paradoxos que compõem a financeirização do urbano advém das diferentes espaço-temporalidades que envolvem os atores presentes no processo. Há, aqui, "processos que implicam diferentes quadros espaçotemporais no interior dos quais operam o capital e o trabalho" (HARVEY, 2018, p. 144), dificultando nossa compreensão acerca da circulação do capital fixo ao longo dos fluxos de valorização. Modificando a indagação original de Harvey - Como o valor da máquina é transferido às mercadorias produzidas se não há transmissão material? - podemos perguntar como o valor do espaço construído (urbanizado) é transferido à circulação e reprodução do capital? Uma estratégia é associar ao capital fixo o capital portador de juros, através de contratos de aluguel ou de empréstimos (da mesma maneira acontece com facções produtivas do capital que precisam alugar ou adquirir máquinas). Porém, como já advertia Marx (2011, p. 589. In.: HARVEY, 2018, p. 147) nos Grundrisse, "A parte da produção orientada para a produção do capital fixo não produz objetos da fruição 
imediata", o que interfere decisivamente na realização do valor; para Harvey (2018, p. 149) há aqui uma profunda e incontornável contradição nesse processo:

A "matéria escura" do antivalor fornecido pela circulação de capital portador de juros demanda sua parcela da produção futura de valor, que por sua vez precisa aumentar continuamente para cobrir o custo exponencialmente crescente dos juros a pagar. [...] o capital fixo "compromete a produção dos anos seguintes", "antecipa o trabalho futuro como valor equivalente" e, assim, exerce um poder coercitivo sobre os usos futuros. Esse poder coercitivo se faz presente também na dimensão do lugar. Capital fixo e imóvel incorporado à terra precisa ser usado in situ para que o valor seja resgatado no curso de sua vida útil. Há um paradoxo nisso. Uma forma de capital concebida para fornecer a infraestrutura física num local a fim de liberar a mobilidade espacial do capital em geral acaba forçando o fluxo de capital para dentro daquele espaço delimitado pelo capital fixo, caso contrário o valor deste último será desvalorizado, com graves consequências para o capital portador de juros (por exemplo, os fundos de pensão) que o financiou. Essa é uma das maneiras poderosas pelas quais vem à tona a tendência do capital a crises.

39 Seguindo nossa argumentação, o processo de metropolização do espaço - à luz da financeirização - tem comprometido o futuro a partir das "formas fixas de fazer as coisas", levando à perda de flexibilidade por parte do capital. As "cidades do amanhã”, portanto, já nascem comprometidas com as demandas da acumulação do agora.

\section{Considerações finais}

40 Ao pensarmos nas Subprime Cities de Manuel Aalbers (2012) ou nas "Cidades do Amanhã" que mencionamos ao longo do tópico anterior, temos em conta que o processo de financeirização do urbano vem ampliando tanto a segregação quanto a banalização do espaço. Dessa maneira, a produção alienadora do espaço é elevada a níveis - e limites - nunca imaginados, sob o signo da máxima mercadificação do espaço e, portanto, da cidade.

41 Podemos argumentar que tal condição - mercadificação do espaço e da cidade sustenta-se através das rendas de monopólio, que têm como único limite para a acumulação a disposição do mercado em pagar por uma determinada exclusividade associada à mercadoria. Considerando a metropolização do espaço, a transformação do solo urbano em mercadoria pode auferir rendas de monopólio cada vez maiores e, dessa maneira, excluindo parcela cada vez maior da população, que não terá condições de pagar o preço de monopólio. Nesse caminho, podemos pensar na renda de monopólio aplicada às cidades - e ao urbano - que passam a ser conduzidas pelo já mencionado empresariamento urbano: disneyficação urbana, turistificação da cidade, brand city entre outras materializações da busca incessante da renda de monopólio sustentada pela singularidade de uma determinada fração do urbano e da metrópole. Ainda dentro desse contexto, lembremos que no caso da renda de monopólio o valor do espaço urbano - transmutado em preço - não é regulado pelo tempo de trabalho necessário à sua produção, mas por sua escassez e pela disposição de pagar daqueles que desejam esse urbano, essa cidade. Contudo, a financeirização do urbano reforça a excepcionalidade e a singularidade - sustentadas pela renda de monopólio; consome-se o espetáculo, a marca.

Uma analogia interessante é feita por Paulani (2016), quando analisa a "evolução" dos logotipos e etiquetas das roupas. Segundo a autora - citando Naomi Klein - até os anos 1970 as etiquetas eram escondidas, posicionadas em locais bastante discretos. Ao final 
dos anos 1970 e no transcorrer da década de 1980 as etiquetas e símbolos das marcas passam a ser "acessórios de moda", "engolindo as próprias roupas". Imaginemos, agora, essa situação para o urbano e a cidade. Temos o ápice da produção alienadora presente no processo de metropolização do espaço.

Ao citarem Giovanni Arrighi (2006), Ribeiro e Diniz (2017, p. 360) lembram que a fase de expansão financeira representa o momento no qual "os capitais se libertam de sua forma mercadoria". Vale destacar que novas formas de acumulação surgem em meio à financeirização, visto que todas as dimensões da vida passam a ser mercantilizáveis; o consumo ostensivo de produtos culturais (RIBEIRO e DINIZ, 2017, p. 361) pode indicar uma das formas de se libertar da sua forma mercadoria, integrando as fases de expansão financeira (ARRIGHI, 2006 e RIBEIRO e DINIZ, 2017) e, assim, passando a ser o leitmotiv das reformas urbanas e dos processos de retorno aos centros antigos, que disseminam o consumo da espetacularização do urbano, ou seja, consumo da cidade e não apenas na cidade. Essa busca por novas estratégias de realização da acumulação passa, portanto, pela reprodução do espaço urbano, "isto é, diante das contradições internas do capitalismo em relação à tendência à baixa da taxa de lucro, a busca da realização da mais-valia desloca-se fundamentalmente para a produção do espaço" (CARLOS, 2015, p. 10).

Em suma, "a extensão do capitalismo tomou o espaço, primeiro como recurso, depois como força produtiva, e finalmente como mercadoria reprodutível, através do setor imobiliário. Seu movimento em direção à sua reprodução aponta o urbano" (CARLOS, 2015, p. 15). Fica evidente, portanto, que a financeirização do urbano traz à tona novas formas de alienação e, assim, intensifica a produção alienadora do espaço.

\section{BIBLIOGRAFIA}

ALBERS, Manuel B. Subprime Cities: the political economy of mortgage markets. Blackwell Publishing: 2012.

AGLIETA, Michel. Segunda Parte. Cap. IV - Concentración y centralización del Capital. Itens: 1. Definición y causas de la concentración del capital. 1.1 Concentración y centralización del capital industrial. In: Regulación y Crisis del Capitalismo. $3^{\text {a }}$ ed. México: Siglo Veintiuno Editores1986.

ARRIGHI, Giovanni. O Longo Século XX: dinheiro, poder e as origens de nosso tempo. Rio de Janeiro: Contraponto. São Paulo: Editora Unesp, 2006.

CARLOS, Ana Fani Alessandri. A condição espacial. São Paulo: Contexto, 2011.

CARLOS, Ana Fani Alessandri (Org.). Crise Urbana. 1. Ed.; $1^{\underline{a}}$ reimpressão. São Paulo: Contexto, [2015] 2018.

CARLOS, Ana Fani Alessandri. A reprodução do espaço urbano como condição da acumulação. In.: FERREIRA, Alvaro; RUA, João; MATTOS, Regina Célia de (Orgs.). O espaço e a metropolização: cotidiano e ação. Rio de Janeiro: Consequência, 2017. pp. 51-70. 
CHESNAIS, François. A Mundialização Financeira: gênese, custos e riscos. São Paulo: Xamã, [1996] 1998.

CHESNAIS, François. A teoria do regime de acumulação financeirizado: conteúdo, alcance e interrogações. Economia e Sociedade, Campinas, v. 11, n. 1 (18), pp. 1-44, jan.-jun. 2002.

HARVEY, David. O Novo Imperialismo. São Paulo: Edições Loyola, [2003] 2014.

HARVEY, David. Neoliberalismo: história e implicações. São Paulo: Edições Lyola. [2005] 2008.

HARVEY, David. O Enigma do Capital: e as crises do capitalismo. São Paulo: Ed. Boitempo, 2011.

HARVEY, David. Os Limites do Capital. São Paulo: Boitempo, [1982] 2013.

HARVEY, David. 17 contradições e o fim do capitalismo. São Paulo: Ed. Boitempo, [2014] 2016.

HARVEY, David. A loucura da razão econômica: Marx e o capital no século XXI. 1ª̣. Ed. São Paulo: Boitempo, 2018.

KLINK, Jeroen e BARCELLOS, Marcos de Souza. Financeirização: conceitos, experiências e a relevância para o campo do planejamento urbano brasileiro. Cadernos Metrópole. São Paulo, v. 19, n. 39, pp. 379-406, maio/ago. 2017.

MARX, Karl. O Capital: Crítica da Economia Política. Livro III: O processo global da produção capitalista. São Paulo: Editora Boitempo, 2017

PAULANI, Leda Maria. Acumulação e rentismo: resgatando a teoria da renda de Marx para pensar o capitalismo contemporâneo. Revista de Economia Política, São Paulo, v. 36, n. 3, pp. 514-535, Sept. 2016.

PEREIRA, Paulo Cesar Xavier Pereira. Preço e valor na financeirização da produção do espaço. In.: FERREIRA, Alvaro; RUA, João; MATTOS, Regina Célia de (Orgs.). O espaço e a metropolização: cotidiano e ação. Rio de Janeiro: Consequência, 2017, pp.171-211.

RIBEIRO, Luiz César de Queirós e DINIZ, Nelson. Financeirização, mercantilização e reestruturação espaço-temporal: reflexões a partir do enfoque dos ciclos sistêmicos de acumulação e da teoria do duplo movimento. Cadernos Metrópole, São Paulo, v. 19, n. 39, pp. 351-377, maio/ago. 2017.

RUFINO, Maria Beatriz Cruz. Financeirização do imobiliário e transformação na produção do espaço: especificidades da reprodução do capital e expansão recente na metrópole paulistana. In.: FERREIRA, Alvaro; RUA, João; MATTOS, Regina Célia de (Orgs.). O espaço e a metropolização: cotidiano e ação. Rio de Janeiro: Consequência, 2017, pp.213-240.

SANFELICI, Daniel Mello. A metrópole sob o ritmo das finanças: implicações socioespaciais da expansão imobiliária no Brasil. 2013. Tese (Doutorado em Geografia Humana) - Faculdade de Filosofia, Letras e Ciências Humanas, Universidade de São Paulo, São Paulo, 2013.

\section{NOTAS}

1. Vigaristas e profetas são expressões utilizadas por Karl Marx n'O Capital, Livro III, para se referir à classe dos financistas e rentistas.

2. Investimentos conhecidos por hot money ou foot loose são aqueles marcados por forte instabilidade e, portanto, de curto prazo. Essa condição é resultante da busca incessante por melhor rentabilidade e maior retorno àqueles que investiram seu capital.

3. Tradução: Oferta pública inicial, ocorre quando uma empresa abre capital na bolsa de valores. 
4. Tradução: Banco de terras, também correspondendo ao estoque de terras de uma determinada empresa ou de um proprietário individual.

\section{RESUMOS}

A relação entre o setor financeiro e a reprodução do espaço urbano nos traz uma série de reflexões, sobretudo acerca da necessária distinção crítica entre os rendimentos da propriedade do dinheiro e os rendimentos da propriedade da terra. Desta feita, o presente artigo procurará analisar a imbricada relação do setor financeiro com o processo de empresariamento urbano nas novas formas de gestão urbana, contribuindo, assim, para discussão do caráter dialético da relação entre a produção do espaço urbano e a financeirização. Para tanto, dedicaremos a primeira seção à contextualização histórico-geográfica em que o setor financeiro passou ao plano central da acumulação capitalista, para após dedicarmos atenção à relação entre financeirização e urbanização. Por fim, teceremos algumas considerações acerca do tema proposto.

Les connexions intimes entre le secteur financier et la reproduction de l'espace urbain nous amène à une série de réflexions, notamment sur la nécessaire distinction critique entre les revenus de la propriété monétaire et les revenus de la propriété foncière. Ainsi, cet article analyse les rapports entre le secteur financier et le processus d'entrepreneuriat urbain dans les nouvelles formes de gestion urbaine, contribuant ainsi à la dialectique entre la production de l'espace urbain et la financiarisation. Ainsi, la première section est une contextualisation historico-géographique dans laquelle le secteur financier est devenu le centre de l'accumulation capitaliste. A la suite, on consacre notre attention à la relation entre financiarisation et urbanisation. Enfin, nous ferons quelques considérations sur le thème proposé.

The relationship between the financial sector and the reproduction of urban space brings us a series of reflections, especially about the necessary critical distinction between income from money ownership and income from land ownership. This time, this article will seek to analyze the intertwined relationship of the financial sector with the process of urban entrepreneurship in new forms of urban management, thus contributing to the discussion of the dialectical nature of the relationship between the production of urban space and financialization. Therefore, we will dedicate the first section to the historical-geographical contextualization in which the financial sector became the central plan of capitalist accumulation, and after that, we will devote attention to the relationship between financialization and urbanization. Finally, we will make some considerations about the proposed theme.

La relación entre el sector financiero y la reproducción del espacio urbano nos trae una serie de reflexiones, especialmente sobre la necesaria distinción crítica entre los ingresos de la propiedad del dinero y los ingresos de la propiedad de la tierra. En esta ocasión, este artículo buscará analizar la relación entrelazada del sector financiero con el proceso de emprendimiento urbano en nuevas formas de gestión urbana, contribuyendo así a la discusión del carácter dialéctico de la relación entre la producción de espacio urbano y la financiarización. Por tanto, dedicaremos el primer apartado a la contextualización histórico-geográfica en la que el sector financiero se convirtió en el plan central de la acumulación capitalista, y posteriormente, dedicaremos la atención a la relación entre financiarización y urbanización. Finalmente, haremos algunas consideraciones sobre el tema propuesto. 
ÍNDICE

Keywords: financialization; capital reproduction; space reproduction; land income; capital income.

Mots-clés: financiarisation; reproduction du capital; reproduction de l'espace; revenu foncier; revenu du capital.

Palabras claves: financiarización; reproducción del capital; reproducción del espacio; renta de la tierra; renta del capital.

Palavras-chave: financeirização; reprodução do capital; reprodução do espaço; renda fundiária; renda do capital.

\section{AUTOR}

\section{FREDERICO BASSO MONTANARI}

Mestre e Doutorando pelo Programa de Pós-Graduação em Geografia da PUC-RIO, pesquisador do Núcleo de Estudos e Pesquisa em Espaço e Metropolização (NEPEM). E-mail:

fredpaulista@gmail.com 